\title{
PENURUNAN KADAR BOD, COD DAN TSS PADA LIMBAH TAHU MENGGUNAKAN EFFECTIVE MICROORGANISM-4 (EM4) SECARA AEROB
}

\author{
Kartika Lingga Sari, Zulfikar Ali As, Hardiono \\ Poltekkes Kemenkes Banjarmasin Jurusan Kesehatan Lingkungan \\ Jl. H. Mistar Cokrokusumo No.1A Banjarbaru Kalimantan Selatan 70714 \\ E-mail: kartikalinggasari@yahoo.com
}

\begin{abstract}
Decreased Levels BOD, COD and TSS Waste Of Tahu Using Effective Microorganism-4 (EM4) In Aerobic. Wastewater was generated from industry tahu still contains levels of polluters such as BOD, COD and TSS are still high that can pollute waterways, Therefore it must be lowered levels before discharge into waterways. One way to do is wastewater treatment with $\mathrm{EM}_{4}$. This type of research was a quasi experiments aimed to determine the reduced levels of BOD, COD and TSS waste of tahu with wastewater treatment using the activator Effective Microorganism-4 $\left(\mathrm{EM}_{4}\right)$ in aerobic with variation concentrations of $0 \%, 3 \%, 5 \%, 7 \%$ and retention time of 72 hours, 144 hours, 216 hours. The results showed the highest decrease levels wastewater concentration treatment of $7 \%$ $\mathrm{EM}_{4}$ with retention time of 216 hours with a BOD value 399,9 mg/L (88,8\%), COD 1355,2 $\mathrm{mg} / \mathrm{L}(85,3 \%)$ and TSS $287 \mathrm{mg} / \mathrm{L}(72,7 \%)$. Data analysis used two-way anova in the treatment group $\mathrm{EM}_{4}$ concentration and retention time obtained $\mathrm{p}$ value $=0.000$ and $\alpha=$ 0.05 the results showed that there were significant differences due to variations in the concentration of $\mathrm{EM}_{4}$, due to the retention time and due to the effects of interactions $\mathrm{EM}_{4}$ concentration with retention time. The treatment results still exceeded the quality standard so before doing aerobic treatment, the first can do anaerobic treatment, so that wastewater treatment is getting better effluent.
\end{abstract}

Keywords: Waste of tahu; levels of BOD; COD;TSS; EM4; retention time.

\begin{abstract}
Abstarak : Penurunan Kadar BOD, COD dan TSS pada Limbah Tahu Menggunakan Effective Microorganism-4 (EM4) Secara Aerob. Limbah cair yang dihasilkan dari industri tahu mengandung kadar pencemar seperti BOD, COD dan TSS masih tinggi yang dapat mencemari perairan, oleh karena itu harus diturunkan kadarnya sebelum dibuang ke perairan. Salah satu cara yang dapat dilakukan adalah pengolahan limbah cair dengan $\mathrm{EM}_{4}$. Jenis penelitian ini adalah penelitian quasi eksperimen yang bertujuan untuk mengetahui penurunan kadar BOD, COD dan TSS limbah tahu dengan pengolahan limbah menggunakan aktivator Effective Microorganism-4 (EM 4 ) secara aerob dengan variasi konsentrasi 0\%, 3\%, $5 \%, 7 \%$ dan waktu tinggal 72 jam, 144 jam, 216 jam. Hasil penelitian menunjukkan penurunan kadar limbah terbesar pada pengolahan konsentrasi $\mathrm{EM}_{4} 7 \%$ dengan waktu tinggal 216 jam dengan nilai BOD 399,9 mg/L (88,8\%), COD 1355,2 mg/L (85,3\%) dan TSS $287 \mathrm{mg} / \mathrm{L}(72,7 \%)$. Analisis data menggunakan two way anova pada kelompok perlakuan konsentrasi $\mathrm{EM}_{4}$ dan waktu tinggal diperoleh $\mathrm{p}=0,000$ dan $\alpha=0,05$ hasil tersebut menunjukan bahwa ada perbedaan bermakna akibat variasi konsentrasi $\mathrm{EM}_{4}$, akibat waktu tinggal dan akibat efek interaksi konsentrasi $\mathrm{EM}_{4}$ dengan waktu tinggal. Hasil pengolahan masih melebihi baku mutu, jadi sebelum melakukan pengolahan aerob dapat melakukan pengolahan anaerob lebih dulu sehingga pengolahan limbah mendapatkan effluent yang lebih baik.
\end{abstract}

Kata Kunci: Limbah tahu; kadar BOD; COD; TSS; EM4; waktu tinggal.

\section{PENDAHULUAN}

Tahu adalah makanan tradisional masyarakat Indonesia yang sangat digemari karena rasanya yang lezat, bergizi tinggi dan harganya murah. Selain itu proses pembuatan tahu juga mudah, sehingga industri tahu pada umumnya beroperasi dalam bentuk usaha rumah tangga. Walau usaha ini dalam bentuk usaha rumah tangga, namun disebabkan 
industri ini cukup banyak jumlahnya maka limbah yang dihasilkan disangsikan berdampak signifikan terhadap lingkungan karena limbah yang dihasilkannya pada dasarnya tidak dikelola dan dialirkan langsung ke dalam perairan terdekat.

Saat oksigen tidak mencukupi untuk mengurai bahan-bahan organik tersebut dan limbah dibuang ke lingkungan perairan secara terus menerus maka dapat berdampak negatif, lingkungan penerima akan mengalami titik jenuh jika beban cemaran yang masuk melebihi daya tampung lingkungan sehingga dapat menimbulkan bau, gangguan estetika dan merusak ekosistem perairan [1].

Melihat dampak yang ditimbulkan dari limbah tahu, seharusnya sebelum dibuang harus dilakukan pengolahan yang memadai terlebih dahulu. Pengolahan limbah tahu terkendala karena membutuhkan teknologi yang memadai dan biaya yang besar, sementara umumnya produksi tahu dilakukan di skala rumah tangga. Oleh karena itu perlu alternatif pemecahan masalah agar industri tahu ini dapat mengolah limbah cair tahu dengan biaya yang murah, mudah, cepat, dan limbah yang terolah aman ketika dibuang ke lingkungan. Salah satu pengolahan limbah yang mudah, murah, dan cepat yaitu pengolahan limbah tahu secara biologis yang merupakan suatu proses pengolahan limbah dengan memanfaatkan mikroorganisme.

Mikroorganisme yang dapat digunakan untuk pengolahan limbah cair tahu adalah mikroorganisme yang terdapat pada Effective Microorganism-4 $\left(\mathrm{EM}_{4}\right)$ karena $\mathrm{EM}_{4}$ terdiri dari $95 \%$ bakteri Lactobacillus sp (bakteri asam laktat) dan sisanya mengandung beberapa mikroorganisme yaitu, bakteri fotosintetik (Rhodopseudomonas sp.), jamur fermentasi (Saccharomyces $s p$ ), Actinomycetes dan ragi (Yeast). Bakteri asam laktat memfermentasikan bahan organik menjadi asam laktat yang berfungsi untuk mempercepat perombakan bahan organik, dan dibantu oleh jamur fermentasi (Saccharomyces $s p$ ) memfermentasikan bahan organik menjadi senyawa-senyawa organik yang lebih sederhana.

Peneliti menilai bahwa dalam mengolah limbah cair secara biologi dengan bantuan aktivator $\mathrm{EM}_{4}$ dan diberi bantuan suplai oksigen secara terus menerus akan lebih cepat dalam menurunkan kadar pencemar dan juga hal ini bertujuan untuk mengoptimalkan kondisi lingkungan sehingga bakteri pemakan bahan organik dapat tumbuh dengan baik, karena bakteri yang terdapat dalam $\mathrm{EM}_{4}$ merupakan bakteri aerob yang membutuhkan oksigen bebas dalam mendegradasi senyawa organik [2]. Pasokan udara yang lancar juga dapat mencegah terjadinya pengendapan [3].

Oleh karena itu peneliti tertarik mencoba melakukan penelitian untuk mengolah limbah cair tahu menggunakan aktivator $\mathrm{EM}_{4}$ dengan beberapa variasi konsentrasi yaitu $0 \%, 3 \%, 5 \%$ dan $7 \%$. Konsentrasi yang digunakan mengambil rentang dosis optimum dari penelitian terdahulu dan diberi aerasi terus menerus selama 9 hari untuk mengetahui seberapa efektifnya $\mathrm{EM}_{4}$ dalam menurunkan kadar BOD, COD dan TSS pada limbah tahu, kaitannya untuk mengembangkan teknologi pengolahan limbah yang murah, cepat, mudah pengoperasiannya dan tidak memiliki dampak untuk lingkungan sekitar setelah dilakukan pengolahan serta harganya terjangkau, khususnya untuk industri tahu tersebut.

\section{BAHAN DAN CARA PENELITIAN}

Desain penelitian yang digunakan yaitu Pretest and Posttest with Control Group. Desain ini melengkapi kelompok kontrol maupun pengukuran perubahan, tetapi juga menyertakan tes awal untuk menilai perbedaan antara dua kelompok. Populasi pada penelitian ini adalah semua limbah tahu yang dihasilkan oleh industri tahu di Jl. Manggis, Kecamatan Landasan Ulin Timur, Kota Banjarbaru. Yang men jadi variabel penelitian ini adalah variabel bebas yaitu konsentrasi $\mathrm{EM}_{4} 0 \%, 3 \%, 5 \%$, $7 \%$ dan waktu tinggal 72 jam, 144 jam 216 jam. Variabel terikat kadar BOD, COD 
dan TSS. Variabel kontrol $\mathrm{pH}$ dan suhu. Metode pengumpulan data yaitu data umum dan data khusus, data umum meliputi gambaran umum industri tahu di Jl. Manggis, Kecamatan Landasan Ulin Timur, Kota Banjarbaru, alur produksi pembuatan tahu. Data khusus yaitu hasil pengukuran kadar BOD, COD dan TSS sebelum dan sesudah pengolahan. Sumber data terdiri dari data primer dan data sekunder, data primer adalah hasil pengukuran kadar BOD, COD dan TSS sebelum dan sesudah pengolahan, data sekunder meliputi data umum dan hasil wawancara dengan pemilik dan pekerja industri tahu. Cara pengumpulan data yaitu dengan mencatat data umum dari hasil wawancara dengan pemilik industri tahu sesuai dengan keperluan dan melakukan pemeriksaan laboratorium. Pengolahan data yaitu menggunakan analisis uji Twoway Anova[4].

\section{HASIL PENELITIAN DAN PEMBAHASAN}

Hasil pengukuran kadar BOD, COD dan TSS sebelum pengolahan adalah sebagai berikut.

Tabel 1. Hasil Pengukuran Kadar Bahan Organik Sebelum Pengolahan

\begin{tabular}{ccccc}
\hline No & Parameter & Satuan & Kadar & Baku mutu* \\
\hline 1 & BOD & $\mathrm{mg} / \mathrm{L}$ & 3.468 & 150 \\
2 & $\mathrm{COD}$ & $\mathrm{mg} / \mathrm{L}$ & 9.680 & 300 \\
3 & $\mathrm{TSS}$ & $\mathrm{mg} / \mathrm{L}$ & 1.055 & 100 \\
4 & $\mathrm{pH}$ & 4 & $6,0-9,0$ \\
\hline \multicolumn{2}{l}{ Keterangan } & ${ }^{*}$ Permen LH No. 5/2014 tentang & Air Limbah Bagi Usaha dan/atau Kegiatan Pengolahan Kedelai
\end{tabular}

Tabel 1 menunjukkan bahwa semua parameter melebihi baku mutu oleh karena itu perlu suatu pengolahan limbah cair agar tidak membahayakan lingkungan.

Tabel 2. Hasil Pengukuran Kadar BOD Air Limbah Tahu Sesudah Pengolahan

\begin{tabular}{cccccc}
\hline $\begin{array}{c}\text { Waktu } \\
\text { Tinggal } \\
\text { (Jam) }\end{array}$ & \multicolumn{6}{c}{ Kadar BOD Sesudah Pengolahan dengan $\mathrm{EM}_{4}(\mathrm{mg} / \mathrm{L})$} & sig \\
& $0 \%$ & $3 \%$ & $5 \%$ & $7 \%$ & \\
\hline 72 & $3.015,4$ & $1.926,7$ & $1.663,5$ & 1.383 & \\
144 & $2.593,4$ & 956,1 & 653,5 & 526,5 & 0,00 \\
216 & $2.132,3$ & 625,9 & 422,6 & 399,9 & \\
\hline
\end{tabular}

Tabel 2 menunjukkan bahwa seiring bertambahnya waktu pengamatan kadar BOD masing-masing perlakuan semakin menurun. Dan dapat dilihat kadar BOD dengan penambahan EM4 3\%, $5 \%$ dan $7 \%$ jauh turun lebih cepat dibandingkan dengan EM4 0\%, walaupun dengan waktu pengamatan yang sama. Kemampuan yang paling cepat dalam menurunkan kadar BOD yaitu dengan penambahan $\mathrm{EM}_{4}$ 7\% kadar BOD turun menjadi 399,9 mg/L (88,8\%). Namun kadar BOD tersebut belum ada yang memenuhi standar baku mutu limbah cair bagi kegiatan pengolahan kedelai menurut Peraturan Menteri Lingkungan Hidup No. 5 Tahun 2014 untuk parameter BOD yaitu $150 \mathrm{mg} / \mathrm{L}$.

Hasil analisis statistik menggunakan uji Two Way Anova untuk pengukuran kadar BOD limbah tahu sesudah pengolahan nilai significancy $(0,00)$ lebih kecil dibandingkan nilai $\alpha$ $(0,05)$ yang berarti ada perbedaan yang bermakna antar perlakuan tingkat konsentrasi EM4 dan variasi waktu tinggal adalam menurunkan kadar BOD limbah tahu. 
Tabel 3. Hasil Pengukuran kadar COD Air Limbah Tahu dengan Penambahan EM4

\begin{tabular}{|c|c|c|c|c|c|}
\hline \multirow{2}{*}{$\begin{array}{c}\text { Waktu } \\
\text { Tinggal } \\
\text { (Jam) }\end{array}$} & \multicolumn{4}{|c|}{ Kadar COD Sesudah Penambahan $\mathrm{EM}_{4}(\mathrm{mg} / \mathrm{L})$} & \multirow[t]{2}{*}{ Sig } \\
\hline & $0 \%$ & $3 \%$ & $5 \%$ & $7 \%$ & \\
\hline 72 & $7.485,6$ & $6.582,4$ & 5.937 & $5.162,6$ & 0,00 \\
\hline 144 & $6.208,2$ & $4.259,3$ & $3.484,8$ & $2.452,3$ & \\
\hline 216 & $4.645,7$ & $3.226,7$ & $1.548,8$ & $1.290,6$ & \\
\hline
\end{tabular}

Tabel 3 menunjukkan bahwa seiring bertambahnya waktu pengamatan kadar COD masing-masing perlakuan semakin menurun. Dan dapat dilihat kadar COD dengan penambahan $\mathrm{EM}_{4}$ $3 \%, 5 \%$ dan $7 \%$ jauh turun lebih cepat dibandingkan dengan $\mathrm{EM}_{4} 0 \%$, walaupun dengan waktu pengamatan yang sama. Kemampuan yang paling cepat dalam menurunkan kadar COD yaitu dengan penambahan $\mathrm{EM}_{4} 7 \%$ kadar COD turun menjadi 1290,6 mg/L.

Namun kadar COD tersebut belum memenuhi standar baku mutu limbah cair bagi kegiatan pengolahan kedelai menurut Peraturan Menteri Lingkungan Hidup No. 5 Tahun 2014 untuk parameter COD yaitu $300 \mathrm{mg} / \mathrm{L}$.

Hasil analisis statistik menggunakan uji Two Way Anova untuk pengukuran kadar COD limbah tahu sesudah pengolahan nilai significancy $(0,00)$ lebih kecil dibandingkan nilai $\alpha$ $(0,05)$ yang berarti ada perbedaan yang bermakna antar perlakuan tingkat konsentrasi EM4 dan variasi waktu tinggal adalam menurunkan kadar COD limbah tahu.

Tabel 4. Hasil Pengukuran kadar TSS Air Limbah Tahu dengan Penambahan EM4

\begin{tabular}{|c|c|c|c|c|c|}
\hline \multirow{2}{*}{$\begin{array}{c}\text { Waktu Tinggal } \\
\text { (Jam) }\end{array}$} & \multicolumn{4}{|c|}{ Kadar TSS Sesudah Penambahan $\mathrm{EM}_{4}(\mathrm{mg} / \mathrm{L})$} & \multirow{2}{*}{ Sig } \\
\hline & $0 \%$ & $3 \%$ & $5 \%$ & $7 \%$ & \\
\hline 72 & 876 & 646 & 545 & 551 & \multirow{3}{*}{0,00} \\
\hline 144 & 754 & 423 & 384 & 333 & \\
\hline 216 & 676 & 403 & 303 & 287 & \\
\hline
\end{tabular}

Tabel 4 menunjukkan bahwa seiring bertambahnya waktu pengamatan kadar TSS masing-masing perlakuan semakin menurun. Dan dapat dilihat kadar TSS dengan penambahan EM4 $3 \%, 5 \%$ dan $7 \%$ jauh turun lebih cepat dibandingkan dengan EM4 0\%, walaupun dengan waktu pengamatan yang sama. Kemampuan yang paling cepat dalam menurunkan kadar TSS yaitu dengan penambahan EM4 7\% kadar TSS turun menjadi $287 \mathrm{mg} / \mathrm{L}$.

Namun kadar TSS tersebut belum memenuhi standar baku mutu limbah cair bagi kegiatan pengolahan kedelai menurut Peraturan MenterI Lingkungan
Hidup No. 5 Tahun 2014 untuk parameter TSS yaitu $200 \mathrm{mg} / \mathrm{L}$ [5].

Hasil analisis statistik menggunakan uji Two Way Anova untuk pengukuran kadar TSS limbah tahu sesudah pengolahan nilai significancy $(0,00)$ lebih kecil dibandingkan nilai $\alpha$ $(0,05)$ yang berarti ada perbedaan yang bermakna antar perlakuan tingkat konsentrasi EM4 dan variasi waktu tinggal adalam menurunkan kadar TSS limbah tahu.

Hasil pengukuran $\mathrm{pH}$ limbah tahu sesudah pengolahan adalah sebagai berikut. 
Tabel 5. Hasil Pengukuran pH Limbah cair tahu sesudah pengolahan

\begin{tabular}{ccccc}
\hline \multirow{2}{*}{ Waktu Tinggal (jam) } & \multicolumn{5}{c}{ Nilai pH sesudah pengolahan dengan $\mathrm{EM}_{4}$} \\
& $0 \%$ & $3 \%$ & $5 \%$ & $7 \%$ \\
\hline 72 & 4 & 5 & 5 & 5 \\
144 & 4 & 5 & 6 & 6 \\
216 & 5 & 6 & 7 & 7 \\
\hline
\end{tabular}

Tabel 5 menunjukkan bahwa nilai pH sesudah pengolahan, baik dengan penambahan $\mathrm{EM}_{4}$ maupun tanpa $\mathrm{EM}_{4}$ meningkat seiring dengan makin lamanya waktu tinggal yang diberikan. Namun pengolahan air limbah tahu dengan penambahan $\mathrm{EM}_{4}$ dalam waktu pengamatan yang sama jauh lebih cepat dalam meningkatkan nilai $\mathrm{pH}$.

Hasil pengukuran suhu limbah cair tahu sesudah pengolahan adalah sebagai berikut.

Tabel 6. Hasil Pengukuran Suhu Limbah cair tahu sesudah Pengolahan

\begin{tabular}{ccccc}
\hline \multirow{2}{*}{ Waktu Tinggal (jam) } & \multicolumn{5}{c}{ Suhu Air Limbah Sesudah Penambahan Dengan $\mathrm{EM}_{4}\left({ }^{\circ} \mathrm{C}\right)$} \\
& $0 \%$ & $3 \%$ & $5 \%$ & $7 \%$ \\
\hline 72 & 28 & 27 & 27 & 27 \\
144 & 26 & 25 & 25 & 25 \\
216 & 25 & 25 & 24 & 24 \\
\hline
\end{tabular}

Tabel 6 menunjukkan suhu limbah cair tahu sebelum pengolahan sangat tinggi yaitu $31^{\circ} \mathrm{C}$, setelah dilakukan pengolahan dengan waktu tinggal 216 jam,suhu limbah cair tahu baik yang diberi perlakuan dengan konsentrasi $\mathrm{EM}_{4}$ yang berbeda-beda maupun tanpa $\mathrm{EM}_{4}$ sudah mengalami penurunan.

Hasil Persentase penurunan kadar BOD, COD dan TSS berdasarkan variasi konsentrasi $\mathrm{EM}_{4}$ dan lama waktu tinggal adalah sebagai berikut.

Tabel 7. Persentase Penurunan kadar BOD, COD dan TSS Berdasarkan variasi konsentrasi EM4 dan Lama Waktu Tinggal

\begin{tabular}{cccccc}
\hline \multirow{2}{*}{ Parameter } & \multirow{2}{*}{ Waktu Tinggal (Jam) } & \multicolumn{4}{c}{ Penurunan Kadar (\%) } \\
& 72 & 13 & $3 \%$ & $5 \%$ & $7 \%$ \\
\hline \multirow{2}{*}{ BOD } & 144 & 25,2 & 72,4 & 81,2 & 60,1 \\
& 216 & 38,5 & 82 & 87,9 & 88,8 \\
COD & 72 & 22,7 & 32 & 38,6 & 46,7 \\
& 144 & 35,8 & 56,3 & 64 & 74,6 \\
\multirow{2}{*}{ TSS } & 216 & 52 & 66,6 & 84 & 86,6 \\
& 72 & 17 & 38,7 & 48,3 & 48 \\
& 144 & 28,5 & 60 & 63,6 & 68 \\
& 216 & 36 & 61,8 & 71,2 & 72,7 \\
\hline
\end{tabular}

Tabel 7 menunjukkan pengolahan limbah tahu dengan menggunakan penambahan $\mathrm{EM}_{4}$ dapat menurunkan kadar bahan organik sangat besar sesuai konsentrasi $\quad \mathrm{EM}_{4}, \quad$ dibandingkan pengolahan limbah tahu tanpa $\mathrm{EM}_{4}$, walaupun kadar bahan organik tetap akan turun seiring lama waktu tinggal yang diberikan. 


\section{PEMBAHASAN}

Hasil pengukuran kadar bahan organik limbah cair tahu sebelum pengolahan menunjukkan parameter BOD $3468 \mathrm{mg} / \mathrm{l}$, COD $9246 \mathrm{mg} / \mathrm{l}$, TSS 1055 $\mathrm{mg} / \mathrm{l}$ dan $\mathrm{pH}$ 4. Semua parameter tersebut masih melebihi baku mutu yang telah ditetapkan pada Peraturan Menteri Negara Lingkungan Hidup No. 5 Tahun 2014 yang menjelaskan bahwa kadar bahan organik untuk kadar BOD yang diperbolehkan sebesar $150 \mathrm{mg} / \mathrm{l}$, kadar COD sebesar $300 \mathrm{mg} / \mathrm{l}$ dan kadar TSS sebesar $200 \mathrm{mg} / \mathrm{l}$.

Kadar bahan organik yang melebihi standar baku mutu dikarenakan bahan-bahan organik yang terdapat pada limbah cair tahu pada umumnya sangat tinggi berupa protein $40 \%-60 \%$, karbohidrat 25\% - 50\% dan lemak [6]. Semakin lama dan semakin banyak volume limbah maka akan menyulitkan pengelolaan limbah, karena beberapa zat sulit diuraikan oleh mikroorganisme didalam air limbah tahu tersebut.

Komponen terbesar dari limbah cair industri tahu yaitu protein (N-Total) sebesar 226,06 sampai 434,78 mg/l. Sehingga jika limbah cair tahu masuk ke lingkungan perairan akan meningkatkan total nitrogen di perairan tersebut [7] sehingga perlu dilakukan pengolahan terlebih dahulu dengan tujuan air limbah yang dihasilkan tidak mencemari air dan kualitas air sesuai dengan standar baku mutu, mengingat tingginya potensi pencemaran pada perairan.

Hasil penelitian menunjukkan bahwa konsentrasi $\mathrm{EM}_{4} 7 \%$ dengan waktu tinggal 216 jam merupakan penurunan yang paling besar. Kadar BOD yang dihasilkan setelah pengolahan turun menjadi $399,9 \mathrm{mg} / \mathrm{L}$ dengan persentase penurunan sebesar $88,8 \%$. Mengacu pada penelitian yang dilakukan oleh (Arsil \& Supriyanto, 1999) yang juga meneliti tentang pengolahan limbah cair dari industri kecil pengolahan tahu, memperoleh hasil bahwa dengan waktu tinggal 6 hari, kadar BOD dapat turun sebanyak $68,06 \%$, begitu pula penelitian oleh Febrinaldy Safni, Sri Puji Ganefati dan Siti Hani Istiqomah 2010 juga meneliti tentang pengolahan limbah cair dari industri tahu, memperoleh hasil bahwa waktu tinggal 9 hari dengan proses anaerobik diperoleh penurunan kadar BOD sebesar $534 \mathrm{mg} / \mathrm{l}$ dengan persentase penurunan mencapai 76,9\%.

Penurunan kadar BOD yang lebih besar menunjukkan adanya aktifivitas dari bakteri asam laktat (Lactobacillus $s p$ ) yang terdapat dalam $\mathrm{EM}_{4}$. Bakteri tersebut memfermentasikan bahan organik limbah cair tahu menjadi senyawa asam laktat yang berfungsi untuk mempercepat perombakan bahan organik (Isa, 2008). Selain itu adanya kerjasama antara bakteri asam laktat yang terkandung dalam $\mathrm{EM}_{4}$ dengan jamur fermentasi (Saccharomyces $s p$ ) yang juga terkandung dalam $\mathrm{EM}_{4}$ dalam memfermentasikan bahan organik menjadi senyawa - senyawa organik yang lebih sederhana sehingga cenderung lebih cepat dibanding dengan proses penguraian senyawa organik alamiah dalam limbah cair tahu. Adanya penguraian senyawa organik menjadi senyawa yang lebih sederhana secara tidak langsung dapat menurunkan kadar BOD [10].

Hasil penelitian Hanifah dkk (2004), mikroorganisme EM mampu mendegradasi senyawa-senyawa polutan dalam limbah dengan cepat. Mikroorganisme dalam limbah terus menerus melakukan proses metabolisme sepanjang kebutuhan energinya terpenuhi.

Hasil penelitian menunjukkan bahwa kadar COD sesudah pengolahan menggunakan $\mathrm{EM}_{4}$ konsentrasi $7 \%$ dengan waktu tinggal 216 jam, nilai COD $1290,6 \mathrm{mg} / \mathrm{L}$ dengan persentase penurunan sebesar 87,4\%. Tingginya persentase penurunan konsentrasi COD dapat diartikan mikroorganisme $\left(\mathrm{EM}_{4}\right)$ bekerja dengan optimal. Mikroorganisme $\left(\mathrm{EM}_{4}\right)$ mampu mengurai limbah dengan cepat. Mikroorganisme dalam limbah terus menerus melakukan proses metabolisme sepanjang kebutuhan energinya terpenuhi dan akan menghasilkan senyawa-senyawa yang 
dapat memberikan dampak terhadap turunnya nilai COD [8].

Mengacu pada penelitian yang dilakukan oleh Ulum Munawaroh, Mumu Sutisna dan Kancitra Pharmawati yang meneliti tentang penyisihan parameter COD pada limbah cair tahu menggunakan Efektive Mikroorganism-4 mendapatkan hasil penelitian pada hari ke 10 kadar COD menjadi $520 \mathrm{mg} / \mathrm{l}$ dengan persentase penurunan sebesar $94 \%$. Hal ini berkaitan dengan lamanya pemberian waktu perlakuan maka semakin lama limbah cair tahu diperlakukan semakin besar pula penurunan kadar COD.

Penurunan Kadar COD dengan penambahan $\mathrm{EM}_{4}$ jauh lebih cepat, hal ini karena aktifivitas dari bakteri asam laktat (Lactobacillus sp) yang terdapat dalam $\mathrm{EM}_{4}$. Bakteri tersebut memfermentasikan bahan organik limbah cair tahu menjadi senyawa asam laktat yang berfungsi untuk mempercepat perombakan bahan organik [9]. Selain itu adanya bantuan enzim protease yang dihasilkan oleh berbagai jenis mikroba yang terdapat pada $\mathrm{EM}_{4}$ mulai dari bakteri, kapang dan khamir. Protease merupakan enzim yang berperan dalam reaksi yang melibatkan pemecahan protein diantaranya menjadi amonia, nitrit, nitrat, $\mathrm{CO}_{2}, \mathrm{H}_{2} \mathrm{O}$.

Adanya proses pemecahan atau penguraian senyawa organik menjadi senyawa yang lebih sederhana secara tidak langsung dapat menurunkan kadar COD [10].

Didalam air limbah juga mengandung mikroorganisme patogenik yang berbahaya bagi kesehatan, dapat mengganggu proses penguraian limbah, mikroorganisme $\left(\mathrm{EM}_{4}\right)$ mampu menghambat pertumbuhan dan perkembangan mikroorganisme patogen dengan mengeluarkan senyawa-senyawa anti biotik yang juga terkandung di dalamnya.

Hasil penelitian menunjukkan bahwa penurunan kadar TSS terbesar yaitu pada konsentrasi $\mathrm{EM}_{4} 7 \%$ dengan waktu tinggal 216 jam, kadar TSS yang dihasilkan setelah pengolahan turun menjadi $287 \mathrm{mg} / \mathrm{l}$ dengan persentase penurunan sebesar $72,7 \%$.
Penurunan kandungan TSS disebabkan oleh mikroorganisme yang dapat bertahan hidup di limbah cair tahu adalah jenis mikroorganisme Lactobacillus sp (mikroorganisme yang dapat hidup dalam kondisi asam). Pada masa tersebut mikroorganisme $\mathrm{EM}_{4}$ tersebut mengalami fase adaptasi, sehingga mikroorganisme $\mathrm{EM}_{4}$ tersebut mampu beradaptasi dengan lingkungannya yang baru. Seiring waktu pengolahan penurunan kadar TSS semakin besar karena pada fase ini mikroorganisme dalam fase pertumbuhan dimana terjadi pertumbuhan bakteri secara pesat, sehingga dalam pertumbuhannya mikroorganisme membutuhkan makan yang berupa limbah tahu tersebut dan secara langsung akan berdampak pada penurunan kadar TSS.

Hasil post hoc tests pada LSD perlakuan konsentrasi $7 \%$ dengan waktu tinggal 216 jam diketahui paling bagus dalam menurunkan kadar BOD, COD dan TSS pada limbah tahu. Namun kadar BOD, COD dan TSS tersebut belum mencapai standar baku mutu yang telah ditetapkan Peraturan Menteri Negara Lingkungan Hidup No. 5 Tahun 2014 tentang air limbah bagi usaha dan/atau kegiatan pengolahan kedelai.

Nilai pH pada limbah cair tahu dari masing-masing variasi konsentrasi mengalami peningkatan sampai menjadi $\mathrm{pH}$ netral selama proses pengolahan dan nilai pH tersebut sudah mencapai bakumutu menurut Peraturan Menteri Negara Lingkungan Hidup No. 5 Tahun 2014 tentang Air Limbah Bagi Usaha dan/atau Kegiatan Pengolahan Kedelai yang menjelaskan bahwa $\mathrm{pH}$ normal untuk untuk limbah cair tahu sebesar 6,09,0 .

Berdasarkan penelitian [9], bakteri yang terkandung di dalam limbah menghasilkan amoniak yang dapat meningkatkan nilai pH. Bakteri asam laktat mengubah karbohidrat menjadi asam laktat. Asam laktat digunakan oleh ragi dan jamur membentuk alkohol atau ester, sehingga $\mathrm{pH}$ naik. Sedangkan menurut Jasmiyati dkk (2010), kenaikan 
pH yang terjadi pada limbah cair tahu yang diberi $\mathrm{EM}_{4}$ disebabkan karena adanya mikroorganisme yang ada di dalam $\mathrm{EM}_{4}$ merombak sisa bahan organik dari limbah cair tahu.

\section{KESIMPULAN DAN SARAN}

Hasil pengukuran kadar bahan organik limbah cair tahu sebelum pengolahan untuk parameter BOD 3.468 $\mathrm{mg} / \mathrm{L}$, COD $9.680 \mathrm{mg} / \mathrm{L}$, TSS $1.055 \mathrm{mg} / \mathrm{L}$ dan $\mathrm{pH}$ 4. Kadar bahan organik limbah cair tahu yang diolah dengan menggunakan aktivator $\mathrm{EM}_{4} 0 \%, 3 \%, 5 \%$ dan 7\%. Kadar BOD konsentrasi 0\% $2.132,3 \mathrm{mg} / \mathrm{L}$, konsentrasi 3\% 625,9 $\mathrm{mg} / \mathrm{L}$, konsentrasi 5\% 422,6 mg/L dan konsentrasi 7\% 399,9 mg/L. Kadar COD konsentrasi $0 \%$ 4.645,7 mg/L, konsentrasi 3\% 3.226,7 mg/L, konsentrasi 5\% 1.548,8 mg/L dan konsentrasi 7\% 1.290,6 mg/L. Kadar TSS konsentrasi 0\% 676 $\mathrm{mg} / \mathrm{L}$, konsentrasi 3\% $403 \mathrm{mg} / \mathrm{L}$, konsentrasi $5 \% 303 \mathrm{mg} / \mathrm{L}$ dan konsentrasi $7 \% 287 \mathrm{mg} / \mathrm{L}$. Sesudah pengolahan menggunakan $\mathrm{EM}_{4}$ 0\%, 3\%, 5\% dan $7 \%$ secara aerob diperoleh persentase penurunan terbesar untuk parameter BOD yaitu pada pengolahan $\mathrm{EM}_{4}$ konsentrasi 7\% dengan waktu tinggal 216 jam atau setara 9 hari mencapai 88,8\%. Persentase penurunan terbesar untuk parameter COD yaitu pada konsentrasi $\mathrm{EM}_{4} 7 \%$ dengan waktu tinggal 216 jam mencapai $86,6 \%$ dan persentase penurunan terbesar untuk parameter TSS yaitu pada konsentrasi $7 \%$ dengan waktu tinggal 216 jam mencapai 72,7\%. Ada perbedaan yang bermakna antar perlakuan tingkat konsentrasi $\mathrm{EM}_{4}$ dalam menurunkan kadar bahan organik limbah tahu.

Dapat disarankan Kepada para pemilik industri tahu disarankan untuk berusaha semaksimal mungkin untuk mengolah limbah cairnya sebelum dibuang ke badan air. Salah satu alternatif yang dapat digunakan yaitu dengan menggunakan biostarter $\mathrm{EM}_{4}$. Kepada peneliti lain yang ingin mengembangkan penelitian ini, disarankan untuk mengamati penurunan kadar bahan organik yang terjadi dengan melakukan proses pengolahan secara anaerob terlebih dahulu diikuti oleh pengolahan lanjutan berupa proses aerob menurut Metcalf \& Edy dalam bukunya Waste Water Engenering (2003) dapat digunakan untuk mendapat hasil pengolahan yang baik dan memperoleh keuntungan dari kedua proses pengolahan tersebut.

\section{KEPUSTAKAAN}

1. Laurendy, Y., Hairullah, \& Jayanti, S. (2010). Rancang Bangun Alat Pengolahan Biogas Limbah Cair Industri Tahu Di Banjarbaru, Kalimantan Selatan. Banjarbaru: UNLAM.

2. Jasmiyati, Anita, S., \& Thamrin. (2010). Bioremediasi Limbah Cair Industri Tahu Menggunakan Efektif Mikroorganisme (EM4). Ilmu Lingkungan Journal of Enviromental Science.

3. Sugiharto. (1994). Dasar-Dasar Pengolahan Air Limbah. Jakarta: Penerbit Universitas Indonesia.

4. Hidayat, A. A. (2009). Metode Penelitian Keperawatan dan Teknik Analisis Data. Jakarta: Salemba Medika.

5. Peraturan Menteri Lingkungan Hidup No. 5 tahun 2014 tentang Baku Mutu Air Limbah Bagi Usaha Dan/Atau Kegiatan Pengolahan Kedelai.

6. Said, \& Wahjono. (1999). Teknologi Pengolahan Air Limbah Tahu-Tempe dengan Proses Biofilter Anaerob dan Aerob. Jakarta: BPPT.

7. Pohan, N. (2008). Pengolahan Limbah Cair Industri Tahu Dengan Proses Biofilter Aerobik. Tesis Program Studi Teknik Kimia USU .

8. Ginting, P. (2007). Sistem Pengeloaan Lingkungan dan Limbah Industri. Bandung: Yrama Widya .

9. Isa, M. (2008). Pengaruh Pemberian Dosis EM4, Cacing Lumbricus Rubellus da Campuran Keduanya Terhadap Lama Waktu Pengomposan Sampah RUmah Tangga . Fakultas Kesehatan Masyarakat.

10. Avlenda, E. (2009). Penggunaan Tanaman Kangkung (Ipomoea aquatic) Forsk.) Dan Genjer 
(Limnocharis flava (L.) Buch.) Dalam Pengolahan Limbah Cair Pabrik Kelapa Sawit.Bandung: Tesis Pascasarjana Biologi Institut Teknologi Bandung. 
